\title{
Perubahan Garis Pantai pada Musim Timur dan Barat kaitannya dengan Karakteristik Gelombang di Pesisir Kabupaten Takalar, Sulawesi Selatan
}

\author{
Dwi Fajriyati Inaku1*, Nurjannah Nurdin², Dewi Yanuarita Satari' \\ 'Manajemen Sumberdaya Perairan, Departemen Perikanan, Fakultas Ilmu Kelautan dan Perikanan, \\ Universitas Hasanuddin \\ 2Departemen IImu Kelautan, Fakultas Ilmu Kelautan dan Perikanan, Universitas Hasanuddin \\ Jl. Perintis Kemerdekaan Km.10, Tamalanrea, Makassar 90245, Indonesia \\ Email: wiwik.inaku@gmail.com
}

\section{Abstract \\ Coastline Changes in East and West Seasons are related to Wave Characteristics on the Coast of Takalar Regency, South Sulawesi}

Detection of shoreline changes needs to be done to determine changes so that supervision and management planning in a coastal area can be carried out, one of which is on the coast of Takalar Regency, South Sulawesi. This study aims to map changes in the coastline in Takalar Regency in different seasons and to see the effect of the waves on these changes. This study uses Landsat satellite imagery data from 1998-2018, and wave data obtained from Copernicus Marine Environment Monitoring Services (CMEMS). The shoreline data extraction was using the combination of single band and band ratio approach while the shoreline change rate calculation was using the Digital Shoreline Analysis System (DSAS) application. In addition, GeoDa application was used to obtain the regression analysis of the effect of waves on shoreline changes. The results showed that there were similar patterns of shoreline changes between monsoon and west monsoon, although the value were different. Coastal erosion occurs in almost all Takalar coastal area. Some areas that have a high coastal erosion value were the sub-district of South Galesong and Mappakasunggu while the areas that have a high accretion value were the sub-districts of Sanrobone, Mappakasunggu, and Mangarabombang. The waves had a significant influence on changes in shoreline in both the monsoon and west monsoon $(P<0.05)$ with a percentage of $17,2 \%$ for the monsoon and $7.3 \%$ for the west monsoon which indicated there were other factors that influence shoreline change besides the wave factor on the Takalar Coast.

Keywords: shoreline changes, Takalar, coastal erosion, accretion, waves.

\begin{abstract}
Abstrak
Deteksi perubahan garis pantai perlu dilakukan dalam rangka pengawasan dan perencanaan pengelolaan di suatu kawasan, salah satunya di Pesisir Kabupaten Takalar, Sulawesi Selatan. Penelitian ini bertujuan untuk memetakan perubahan garis pantai di Kabupaten Takalar berdasarkan musim dan melihat pengaruh gelombang terhadap perubahan tersebut. Penelitian ini menggunakan data Citra Satelit Landsat tahun 1998-2018, dan data gelombang yang diperoleh dari Copernicus Marine Environment Monitoring Services (CMEMS). Ekstraksi data garis pantai menggunakan pendekatan perkalian single band dan ratio band sedangkan perhitungan laju perubahan garis pantai menggunakan aplikasi Digital Shoreline Analysis System (DSAS). Analisis regresi untuk melihat pengaruh gelombang terhadap perubahan garis pantai menggunakan aplikasi GeoDa. Hasil penelitian menunjukkan terdapat pola yang hampir sama antara perubahan garis pantai musim timur dan musim barat meskipun dengan besaran yang berbeda. Abrasi terjadi hampir di seluruh Pesisir Takalar. Daerah yang memiliki nilai abrasi yang tinggi yaitu Kecamatan
\end{abstract}


Galesong Selatan dan Mappakasunggu sedangkan daerah yang memiliki nilai akresi tinggi yaitu Kecamatan Sanrobone, Mappakasunggu, dan Mangarabombang. Gelombang memberikan pengaruh yang signifikan terhadap perubahan garis pantai baik pada musim timur maupun barat $(P<0,05)$ dengan persentase $17,2 \%$ untuk musim timur dan $7,3 \%$ untuk musim barat yang mengindikasikan terdapat faktor lain yang ikut mempengaruhi perubahan garis pantai selain faktor gelombang di Pesisir Takalar.

Kata Kunci: perubahan garis pantai, Takalar, abrasi, akresi, gelombang

\section{PENDAHULUAN}

Kabupaten Takalar terletak di bagian barat Provinsi Sulawesi Selatan. Pesisir Kabupaten Takalar berhadapan langsung dengan Selat Makassar. Pemanfaatan lahan di pesisir Kabupaten Takalar sebagian besar untuk pemukiman, hutan mangrove, tambak, dan objek wisata. Wilayah Pesisir Kabupaten Takalar saat ini mengalami kondisi yang mengkhawatirkan. Penelitian Eka dan Sakka (2013) tentang kerentanan pantai Takalar menunjukkan bahwa $18 \mathrm{~km}$ dari total $56 \mathrm{~km}$ panjang pantai Takalar memiliki tingkat kerentanan pesisir yang sangat tinggi dan parameter yang paling mempengaruhi kerentanan pesisir Takalar tersebut adalah perubahan garis pantai.

Kurangnya informasi mengenai perubahan garis pantai Kabupaten Takalar secara spasial dan temporal menyebabkan pengawasan perubahan pantai kurang maksimal sehingga pemetaan perubahan garis pantai sangat diperlukan. Informasi mengenai perubahan garis pantai sangat penting dalam berbagai kajian pesisir, salah satunya yaitu untuk keperluan perencanaan pengelolaan kawasan pesisir agar pembangunan yang dilakukan tidak berdampak buruk terhadap lingkungan (Purba et al., 2011; Marfai et al., 2011). Beberapa penelitian mengenai perubahan garis pantai pernah dilakukan di beberapa wilayah diantaranya Purba dan Jaya (2004) di Pesisir Lampung Timur yang menunjukkan bahwa karakteristik gelombang merupakan salah satu faktor yang berperan dalam perubahan garis pantai. Penelitian Nurjaya et al. (2020) di Pantai Barat Kabupaten Tanah Laut Kalimantan Selatan juga menunjukkan bahwa gelombang pasang dapat merusak bakau yang berakibat pada perubahan garis pantai berupa abrasi. Eka dan Sakka (2013) menyatakan bahwa ketinggian gelombang berkaitan dengan bahaya penggenangan air laut dan transport sedimen di pantai. Berdasarkan hal tersebut, maka perlu dilakukan penelitian mengenai perubahan garis pantai berdasarkan musim dan pengaruh gelombang terhadap perubahan tersebut di Pesisir Kabupaten Takalar.

\section{MATERI DAN METODE}

Penelitian ini dilaksanakan di sepanjang pesisir Kabupaten Takalar Sulawesi Selatan, yang meliputi enam kecamatan pesisir yaitu Kecamatan Galesong Utara, Galesong, Galesong Selatan, Sanrobone, Mappakasunggu, dan Mangarabombang (Gambar 1).

Penelitian ini menggunakan data citra satelit Landsat 5 TM, Landsat 7 ETM+, dan Landsat 8 OLI tahun 1998 hingga 2018 untuk memetakan garis pantai. Penggunaan citra satelit resolusi menengah seperti Landsat sesuai untuk kegiatan monitoring garis pantai (Ruiz et al., 2007). Tahapan memetakan garis pantai diawali dengan mengekstrak garis pantai dari citra dengan menggunakan metode perkalian single band dan band ratio. Metode ini dipilih karena dapat memisahkan dengan baik batas antara darat dan air (Alesheikh et al., 2007). Hasil ekstraksi ini kemudian diekspor ke data vektor untuk kemudian diperbaiki tampilannya melalui digitasi on screen menggunakan komposit RGB (Kasim, 2012).

Garis pantai yang didapatkan melalui tahapan ekstraksi selanjutnya dianalisis menggunakan perangkat lunak Digital Shoreline Analysis system (DSAS). DSAS digunakan untuk menghitung jarak perubahan garis pantai berdasarkan waktu dengan metode single transect (Thieler et al., 2009). Metode ini diawali dengan pembuatan transek dengan jarak antar transek sepanjang $100 \mathrm{~m}$. Jarak ini dipilih karena dinilai cukup 
representatif dalam mengukur perubahan garis pantai di pesisir Takalar. Penomoran transek dimulai dari Kecamatan Galesong Utara yang berada di bagian utara dan berakhir di Kecamatan Mangarabombang di bagian Selatan.

Pengukuran jarak perubahan garis pantai yang terlama dengan yang terbaru menggunakan perhitungan Net Shoreline Movement (NSM), sedangkan untuk perubahan rata-rata setiap tahun digunakan perhitungan End Point Rate (EPR). EPR ini didapatkan dengan cara membagi nilai NSM dengan lamanya waktu (tahun), yang secara matematis diformulasikan sebagai berikut (Limber et al., 2007):

$$
\text { Rse }=\frac{\mathrm{x} 0}{\mathrm{t}}
$$

Keterangan: Rse $=$ perubahan rata-rata garis pantai (meter/tahun); $X_{0}=$ ukuran jarak horisontal perubahan suatu titik garis pantai (meter); $\dagger=$ rentang waktu (tahun) posisi garis pantai tersebut.

Perubahan garis pantai yang menghasilkan nilai negatif (-) menandakan abrasi sedangkan akresi akan menghasilkan nilai positif (+) (Kasim, 2010). Selain data citra, digunakan juga data osenaografi berupa data gelombang yang diperoleh secara online melalui Copernicus Marine Environment Monitoring Services (CMEMS). Setelah mendapatkan data tentang perubahan garis pantai dan gelombang, analisis regresi dilakukan untuk melihat pengaruh gelombang terhadap perubahan garis pantai. Analisis regresi ini menggunakan aplikasi GeoDa yang mampu menganalisis data berbasis spasial. Aplikasi ini merupakan aplikasi open source yang pertama kali diperkenalkan oleh Luc Anselin dengan tujuan memfasilitasi eksplorasi dan analisis data spasial (Anselin et al., 2006).

\section{HASIL DAN PEMBAHASAN}

Hasil perhitungan total perubahan garis pantai (Net Shoreline Movement) dalam rentang waktu 20 tahun sejak tahun 1998 hingga tahun 2018 untuk periode musim timur menunjukkan abrasi mendominasi perubahan garis pantai di Pantai Takalar dibandingkan akresi. Terdapat 452 transek atau sekitar $67,7 \%$ pantai Takalar yang mengalami abrasi sedangkan sisanya sekitar $32,3 \%$ mengalami akresi (Gambar 2). Titik abrasi terbanyak dan terbesar terjadi di Kecamatan Galesong Selatan dan Mappakasunggu. Sedangkan titik akresi atau penambahan garis pantai terbanyak terjadi di Kecamatan Sanrobone, Mappakasunggu, dan Mangarabombang (Gambar 3).

Kisaran besaran abrasi pada musim timur di Kecamatan Galesong Selatan dan Mappakasunggu adalah 4,66-7,3 m/tahun dengan titik abrasi tertinggi terjadi di Kecamatan Galesong Selatan, sedangkan

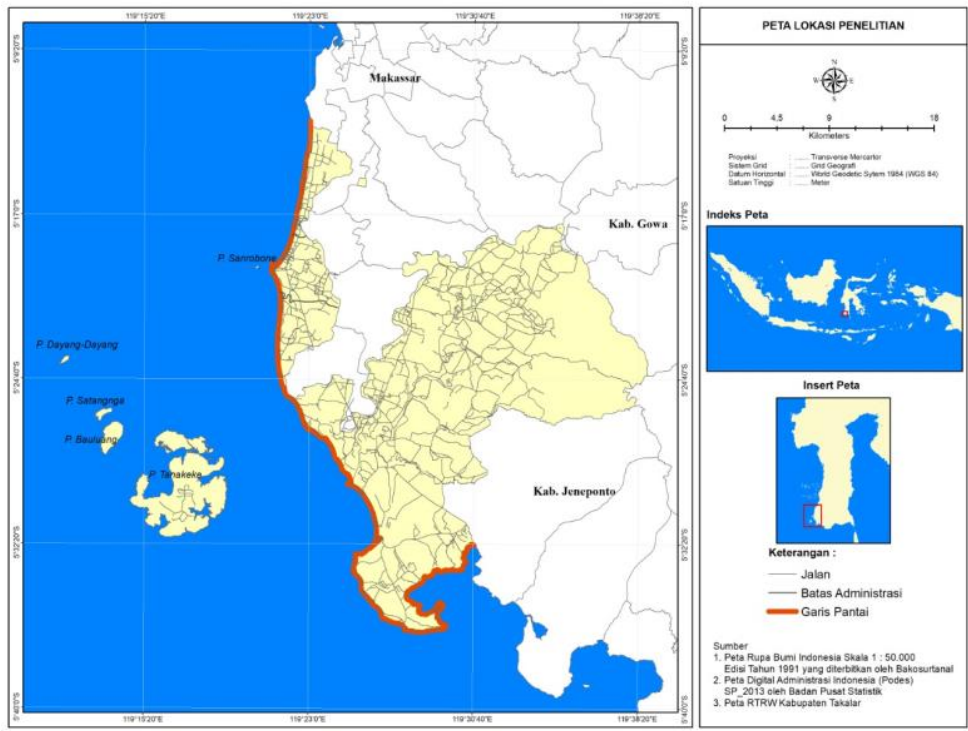

Gambar 1. Peta Lokasi Penelitian 


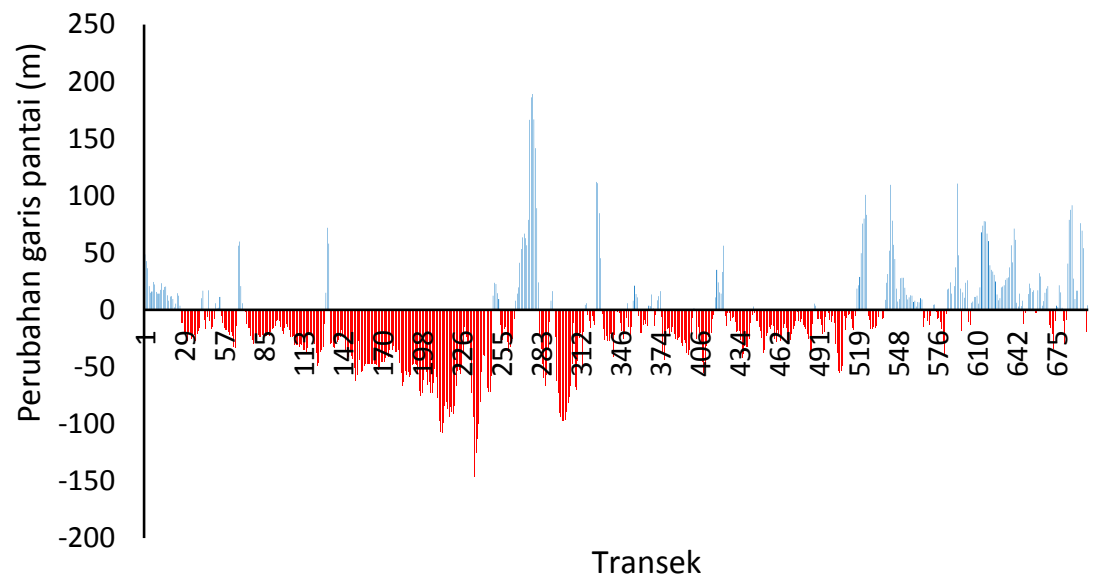

Gambar 2. Perubahan Garis Pantai Pesisir Takalar pada Musim Timur Tahun 1998-2018
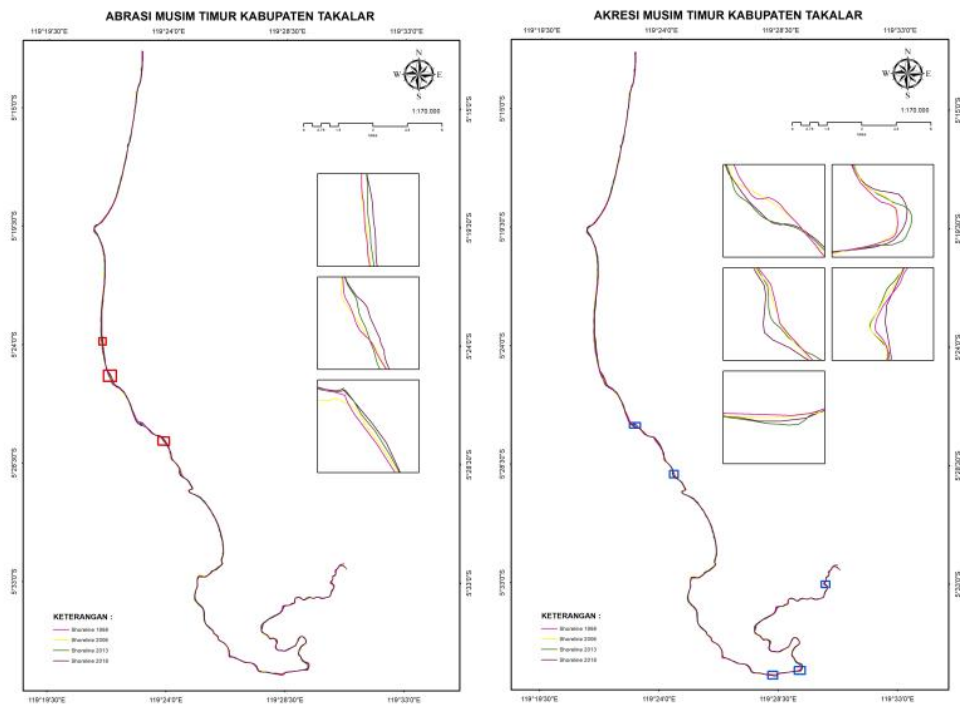

Gambar 3. Lokasi Perubahan Garis Pantai yang Mengalami (a) Abrasi dan (b) akresi pada Musim Timur Tahun 1998-2018

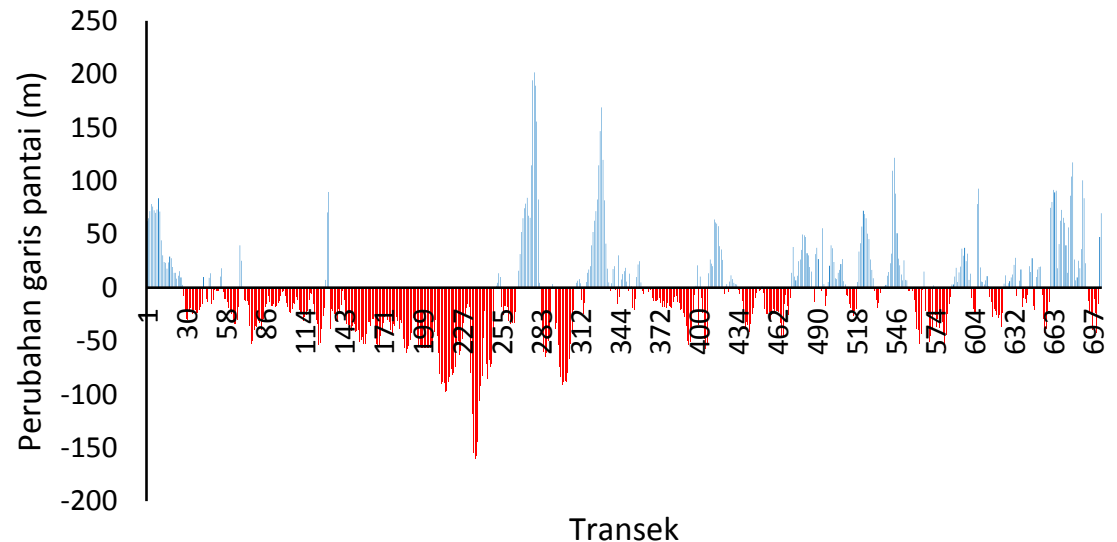

Gambar 4. Perubahan Garis Pantai Pesisir Takalar pada Musim Barat Tahun 1998-2018 
besaran akresi di Kecamatan Sanrobone, Mappakasunggu, dan Mangarabombang berkisar antara 4,37-9,45 m/tahun dengan titik akresi tertinggi terjadi di Kecamatan Sanrobone. Tidak berbeda jauh dengan musim timur, analisis perubahan garis pantai pada musim barat juga menunjukkan abrasi mendominasi perubahan garis pantai di Pesisir Takalar. Terdapat 425 transek atau sekitar $62,5 \%$ pantai Takalar yang mengalami abrasi sedangkan sisanya sekitar $37,5 \%$ mengalami akresi (Gambar 4).

Titik abrasi terbanyak dan terbesar terjadi di Kecamatan Galesong Selatan dan Mappakasunggu. Sedangkan titik akresi atau penambahan garis pantai terbanyak terjadi di Kecamatan Sanrobone, Mappakasunggu, dan Mangarabombang (Gambar 5).

Kisaran besaran abrasi pada musim barat di Kecamatan Galesong Selatan dan Mappakasunggu berkisar antara 4,42-8,02 $\mathrm{m} /$ tahun dengan titik abrasi tertinggi terjadi di Kecamatan Galesong Selatan sedangkan besaran akresi di Kecamatan Sanrobone,
Mappakasunggu, dan Mangarabombang berkisar antara 5,73-10,08 m/tahun dengan titik akresi tertinggi terjadi di Kecamatan Sanrobone.

Abrasi terbesar terjadi di Kecamatan Galesong Selatan karena secara morfologi, pantai Galesong Selatan berbetuk tanjung. Menurut Matondang (2018), pantai yang berbentuk tanjung akan mudah tergerus ketika terjadi hantaman gelombang sehingga mengakibatkan abrasi. Sedangkan pantai yang berbentuk teluk seperti pantai di Kecamatan Mangarabombang cenderung akan mengalami akresi karena material yang tergerus di bagian tanjung akan terbawa dan terendapkan di pantai ini. Hal ini juga sejalan dengan Purba dan Jaya (2004) yang menyatakan pada bagian pantai yang mempunyai tonjolan umumnya dapat terjadi fenomena difraksi gelombang dan gerak eddy sehingga proses erosi akan menjadi lebih intensif. Hasil penggerusan oleh hantaman gelombang tersebut kemudian terangkut dan terendapkan di bagian pantai yang lain sehingga terjadi proses sedimentasi.
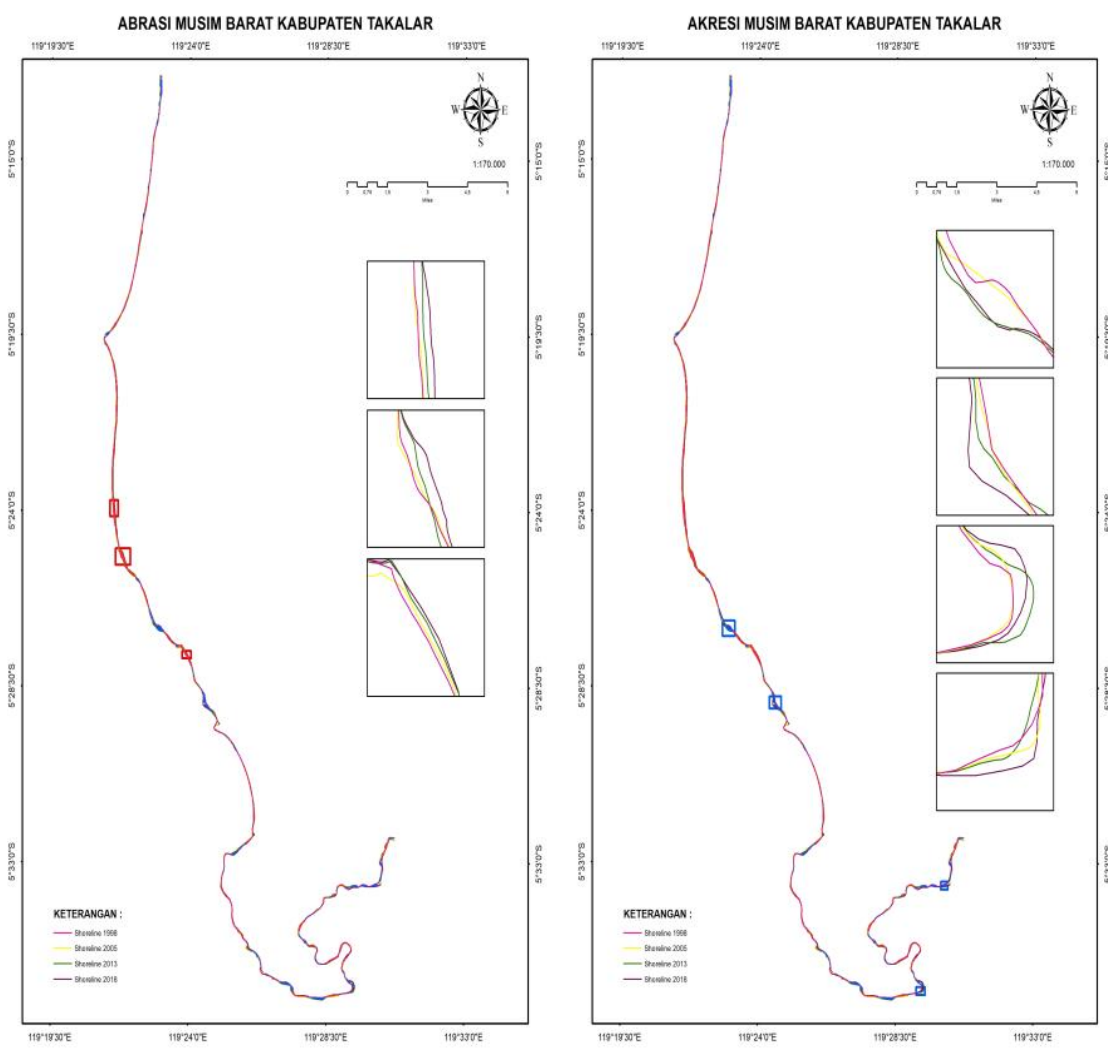

Gambar 5. Lokasi Perubahan Garis Pantai yang Mengalami (a) Abrasi dan (b) akresi pada Musim Barat Tahun 1998-2018 
Namun, berdasarkan hasil penelitian terlihat bahwa lokasi akresi tidak hanya terjadi pada Kecamatan Mangarabombang, akresi juga terjadi di Kecamatan Sanrobone dan Mappakasunggu yang mempunyai garis pantai berkelok-kelok. Hal ini sesuai dengan pendapat Matondang (2018) yang menyatakan bahwa orientasi pantai di Kecamatan Sanrobone dan Mappakasunggu yang cenderung berkelok-kelok menyebabkan sudut gelombang pecah yang terjadi pada setiap grid akan berbeda. Perbedaan tersebut menyebabkan angkutan sedimen sebagian mengarah ke selatan dan sebagian lagi mengarah ke utara sehingga akan ditemukan abrasi dan akresi secara bersamaan pada lokasi ini. Lebih lanjut, berdasarkan hasil penelitian terlihat bahwa akresi yang terjadi di Kecamatan Sanrobone dan Mappakasunggu selain dipengaruhi angkutan sedimen oleh gelombang juga dipengaruhi oleh masukan sedimen dari muara sungai yang berada di sekitar lokasi akresi dan inilah yang menyebabkan akresi di dua kecamatan ini lebih besar dibandingkan yang ditemukan di Kecamatan Mangarabombang.

Selanjutnya, berdasarkan analisis perhitungan rata-rata perubahan garis pantai per tahun (End Point Rate) diketahui bahwa perubahan garis pantai Pesisir Takalar yang disebabkan oleh abrasi memiliki rata-rata tingkat perubahan yang lebih besar dibandingkan dengan akresi baik pada musim timur maupun musim barat. Besaran abrasi yang terjadi pada musim timur berkisar antara 0,001-7,29 m/tahun, sedangkan akresi berkisar antara 0,003-9,45 m/tahun. Abrasi pada musim barat berkisar antara 0,004-8,02 $\mathrm{m} /$ tahun, sedangkan akresi berkisar antara 0,002-10,08 m/tahun.

Gornitz (1991) menyatakan bahwa perubahan garis pantai berupa abrasi yang mencapai lebih dari $2 \mathrm{~m} /$ tahun memiliki nilai kerentanan sangat tinggi, sedangkan perubahan garis pantai akibat akresi lebih dari $2 \mathrm{~m} /$ tahun memiliki nilai kerentanan sangat rendah (Tabel 1). Mengacu pada kategori kerentanan pantai oleh Gornitz (1991), perubahan garis pantai pada musim timur yang terjadi di kecamatan Galesong, Sanrobone, Mappakasunggu, dan Mangarabombang menunjukkan tingkat kerentanan sangat rendah hingga sangat tinggi. Kecamatan Galesong Selatan menunjukkan tingkat kerentanan sedang hingga sangat tinggi, sedangkan kecamatan Galesong Utara menunjukkan tingkat kerentangan sangat rendah hingga tinggi. Hal ini berarti bahwa tingkat kerentanan sangat tinggi ditemukan pada lima kecamatan lainnya selain kecamatan Galesong Utara. Galesong Selatan merupakan satu dari lima kecamatan yang memiliki tingkat kerentanan sangat tinggi dengan nilai abrasi tertinggi mencapai 7,29 m/tahun sekaligus merupakan satu-satunya kecamatan yang mengalami abrasi di sepanjang pantainya pada musim timur (Tabel 2).

Pada musim barat, perubahan garis pantai yang terjadi di kecamatan Galesong, Galesong Utara, Sanrobone, Mappakasunggu, dan Mangarabombang menunjukkan tingkat kerentanan sangat rendah hingga sangat tinggi, sedangkan satu kecamatan lainnya yaitu kecamatan Galesong Selatan menunjukkan tingkat kerentanan sedang hingga sangat tinggi. Hal ini berarti bahwa tingkat kerentanan sangat tinggi ditemukan pada semua kecamatan pesisir yang ada di Kabupaten Takalar. Tidak berbeda jauh dengan hasil yang ditemukan pada musim timur, Galesong Selatan juga merupakan kecamatan yang memiliki tingkat kerentanan sangat tinggi dengan nilai abrasi tertinggi mencapai 8,02 m/tahun sekaligus merupakan satu-satunya kecamatan yang mengalami abrasi di sepanjang pantainya pada musim barat (Tabel 2).

Tabel 1. Kategori Kerentanan Pantai (Gornitz, 1991)

\begin{tabular}{|c|c|c|c|c|c|c|}
\hline Variabel & & $\begin{array}{l}\text { Sangat } \\
\text { rendah }\end{array}$ & Rendah & Sedang & Tinggi & Sangat tinggi \\
\hline $\begin{array}{l}\text { Perubahan } \\
\text { pantai }\end{array}$ & garis & $\geq 2,1$ & $1,0-2,0$ & $1,0--1,0$ & $-1,1--2,0$ & $\geq-2,0$ \\
\hline
\end{tabular}




\section{Pola Perubahan Garis Pantai Musim Timur dan Barat}

Pola perubahan garis pantai pesisir Kabupaten Takalar menunjukkan pola yang cenderung sama antara abrasi dan akresi yang terjadi baik pada musim timur maupun barat sejak tahun 1998 hingga 2018. Hal ini menunjukkan bahwa abrasi dan akresi di pesisir Takalar pada setiap musimnya cenderung terjadi di lokasi yang sama. Perubahan garis pantai akibat abrasi maupun akresi cenderung lebih besar terjadi pada musim barat dibandingkan musim timur (Gambar 6).

Besarnya luasan abrasi pada musim barat disebabkan oleh faktor gelombang. Gelombang yang terjadi pada musim barat lebih tinggi dibandingkan musim timur sehingga menggerus sedimen pantai lebih banyak. Pendleton et al. (2005) menyatakan bahwa ketinggian gelombang berkaitan dengan penggenangan air laut dan transport sedimen di pantai. Tinggi gelombang rata- rata pada musim barat berkisar antara 0,55 2,05 $\mathrm{m}$ dengan periode 1,68-5,04 detik sedangkan pada musim timur rata-rata berkisar antara 0,01-0,46 m dengan periode 0,41-4,14 detik (Gambar 7).

Matondang (2018) menyatakan bahwa pantai yang berbentuk tanjung akan tergerus dan hasil gerusan tersebut akan diangkut ke sisi selatan dalam proses litoral drift. Arah gelombang yang datang dari barat menuju ke pantai Takalar mengakibatkan sedimen terangkut sejajar pantai ke arah utara dan selatan, angkutan sedimen ke arah selatan lebih dominan dengan kisaran mencapai 1,7$512,3 \mathrm{~m}^{3}$ /hari dan rata-rata $302,40 \mathrm{~m}^{3} /$ hari dibanding angkutan sedimen ke arah utara yang berkisar antara 0,2-490,9 $\mathrm{m}^{3} /$ hari dengan rata-rata 114,86 $\mathrm{m}^{3} /$ hari. Hal ini yang menyebabkan bagian selatan pantai Takalar cenderung mengalami akresi, sedangkan bagian utara yang secara morfologi berbentuk tanjung cenderung mengalami abrasi.

Tabel 2. Rata-rata perubahan garis pantai per tahun di Pesisir Takalar sejak tahun 1998-2018

\begin{tabular}{lcccc}
\hline \multirow{2}{*}{ Kecamatan } & \multicolumn{2}{c}{ Kisaran rata-rata abrasi/tahun } & \multicolumn{2}{c}{ Kisaran rata-rata akresi/tahun } \\
\cline { 2 - 5 } & Musim Timur & Musim Barat & Musim Timur & Musim Barat \\
\hline Galesong Utara & $0,013-1,67$ & $0,11-2,64$ & $0,06-2,99$ & $0,007-4,19$ \\
Galesong & $0,6-3,12$ & $0,14-2,67$ & $0,74-4,8$ & $0,37-5,18$ \\
Galesong Selatan & $0,75-7,29$ & $0,78-8,02$ & 0 & 0 \\
Sanrobone & $0,001-3,6$ & $0,01-4,27$ & $0,4-9,45$ & $0,09-10,08$ \\
Mappakasunggu & $0,14-4,88$ & $0,02-4,55$ & $0,21-5,61$ & $0,2-8,4$ \\
Mangarabombang & $0,006-2,76$ & $0,004-2,86$ & $0,003-5,53$ & $0,002-6,08$ \\
\hline
\end{tabular}

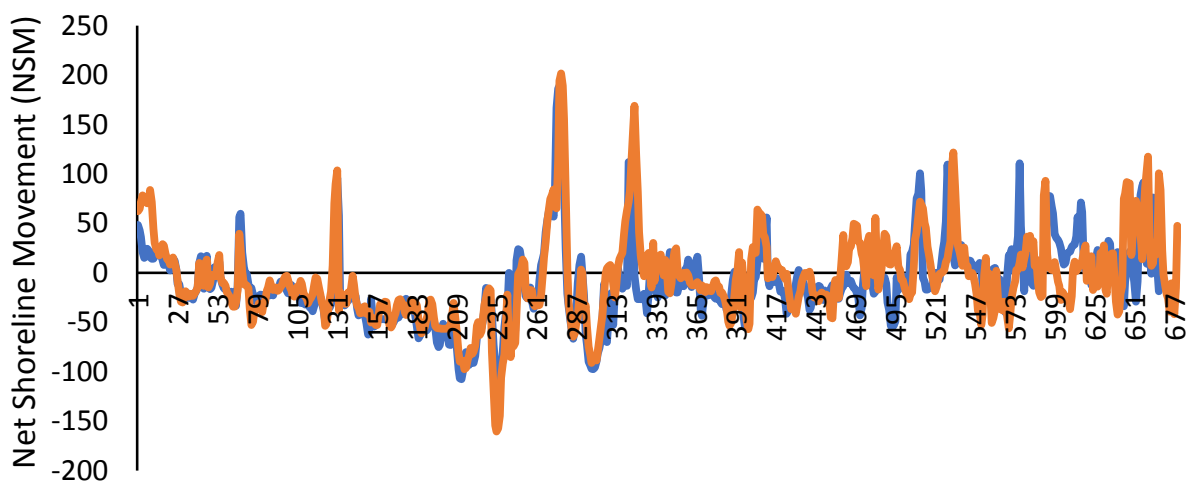

Transek

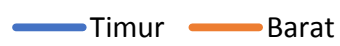

Gambar 6. Pola Perubahan Garis Pantai Pesisir Takalar pada Musim Barat dan Timur 


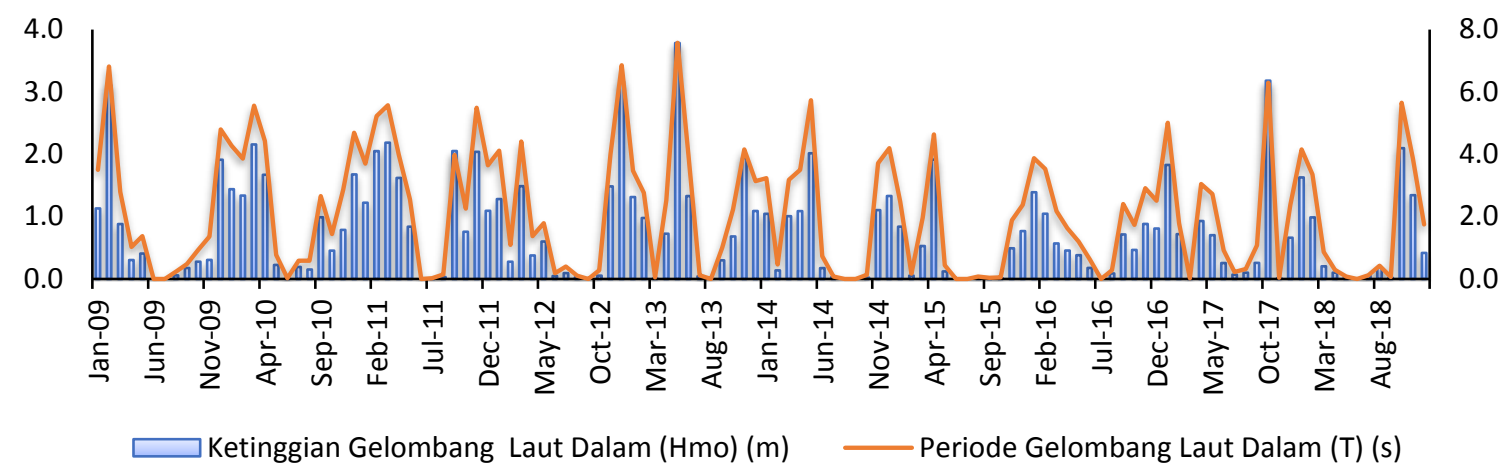

Gambar 7. Karakteristik Gelombang Perairan Takalar berdasarkan analisis data CMEMS

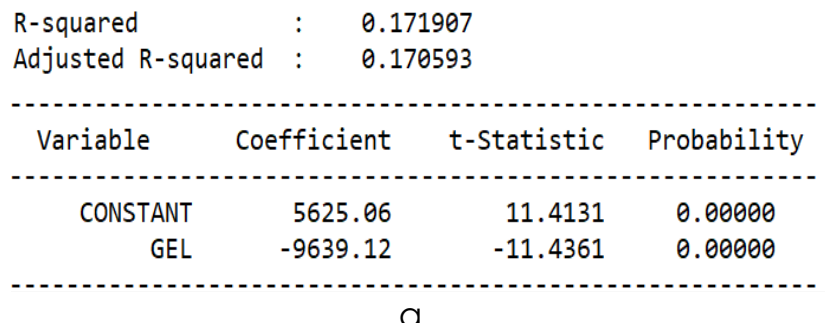

\begin{tabular}{|c|c|c|c|}
\hline Variable & Coefficient & t-Statistic & Probability \\
\hline CONSTANT & 2699.92 & 7.11849 & 0.00000 \\
\hline GEL & -4343.98 & -7.13598 & 0.00000 \\
\hline
\end{tabular}

Gambar 8. Hasil analisis regresi gelombang dan perubahan garis pantai Kabupaten Takalar: (a). Musim timur; (b) Musim barat

\section{Pengaruh Gelombang terhahap Perubahan Garis Pantai pada Musim Timur dan Barat}

Berdasarkan hasil analisis regresi, ditemukan bahwa gelombang memberikan pengaruh yang signifikan terhadap perubahan garis pantai baik pada musim timur maupun musim barat $(P<0,05)$ dengan persentase pengaruh sebesar $17,2 \%$ untuk musim timur dan 7,3\% untuk musim barat yang mengindikasikan terdapat faktor lain selain gelombang yang ikut mempengaruhi perubahan garis pantai di Pesisir Takalar baik pada musim timur maupun musim barat (Gambar 8).

Hasil analisis regresi juga menunjukkan bahwa terdapat pengaruh negatif faktor gelombang terhadap perubahan garis pantai baik pada musim timur maupun musim barat yang berarti semakin tinggi tingkat gelombang maka semakin berkurang luasan garis pantai (abrasi). Hal ini sesuai dengan Purba dan Jaya (2004) yang menyatakan bahwa gelombang yang menghempas di garis pantai akan menggerus pantai dan kemudian hasil gerusan tersebut diangkut oleh arus menyusur pantai dalam proses yang disebut sedimen transpor (littoral drift).

\section{KESIMPULAN}

Hasil penelitian menunjukkan bahwa terdapat perubahan garis pantai di Pesisir Takalar baik pada musim timur maupun musim barat. Kejadian abrasi lebih dominan dibandingkan akresi. Abrasi terbesar terjadi di Kecamatan Galesong Selatan dan Mappakasungu, sedangkan akresi terbesar terjadi di Kecamatan Sanrobone, Mappakasunggu, dan Mangarabombang. Analisis pola perubahan garis pantai menunjukkan abrasi dan akresi pada setiap musimnya cenderung terjadi di lokasi yang sama meskipun dengan besaran nilai yang berbeda. Hasil analisis regresi menunjukkan gelombang memberikan pengaruh yang signifikan terhadap perubahan garis pantai baik pada musim timur maupun barat $(P<0,05)$ dengan persentase sebesar $17,2 \%$ untuk musim timur dan $7,3 \%$ untuk musim barat yang mengindikasikan terdapat faktor lain selain gelombang yang ikut mempengaruhi perubahan garis pantai di Pesisir Takalar baik pada musim timur maupun musim barat. 


\section{UCAPAN TERIMA KASIH}

Kami mengucapkan terima kasih kepada Lembaga Penelitian dan Pengabdian pada Masyarakat Universitas Hasanuddin yang telah memberikan dukungan melalui hibah penelitian internal Universitas Hasanuddin. Kami juga mengucapkan terima kasih kepada Dr. Sarah Hamylton dari Wollongong University, Australia yang telah memberikan masukan dan saran terkait analisis data spasial.

\section{DAFTAR PUSTAKA}

Alesheikh, A.A., Ghorbanali, A. \& Nouri, N. 2007. Coastline change detection using remote sensing, International Journal of Environmental Science and Technology. 4:61-66. doi: 10.1007/BF03325962.

Anselin, L., Syabri, I. \& Kho, Y. 2006. GeoDa: An introduction to spatial data analysis. Geographical Analysis, 38:5-22. doi: 10.11 $11 / \mathrm{j} .0016-7363.2005 .00671 . x$.

Eka, W.S. \& Sakka, S.A., 2013. Analisis Kerentanan Pantai Di Kabupaten Takalar. Jurnal Penelitian Program Studi Geofisika Jurusan Fisika Fakultas MIPA. Universitas Hasanuddin. Makassar.

Gornitz, V. 1991. Global coastal hazards from future sea level rise. Palaeogeography, Palaeoclimatology, Palaeoecology, 89:379398.

Kasim, F. 2010. Laju Perubahan Garis Pantai Menggunakan Modifikasi Teknik Single Transect (ST) dan Metode End Point Rate (EPR): Studi Kasus Pantai Sebelah Utara Indramayu-Jawa barat, Jurnal IImiah Agropolitan, 3:588-600.

Kasim, F. 2012. Pendekatan Beberapa Metode dalam Monitoring Perubahan Garis Pantai Menggunakan Dataset Penginderaan Jauh Landsat dan SIG. Jurnal IImiah Agropolitan, 5:620-635.

Limber, P., List, J. \& Warren, J. 2007. Using Topographic Lidar Data to Deliniate the
North Carolina Shoreline. Coastal Sediments, 7:1837-1850. doi: 10.1061/409 26(239)144

Marfai, M.A., Pratomoatmojo, N.A., Hidayatullah, T., Nirwansyah, A.W. \& Gomareuzzaman, M. 2011. Model Kerentanan Wilayah Pesisir Berdasarkan Perubahan Garis Pantai dan Banjir Pasang (Studi Kasus: Wilayah Pesisir Pekalongan). Universitas Gajah Mada Publisher. 69 hal.

Matondang, M.A. 2018. Model Perubahan Garis Pantai dengan Metode One-Line Model (Studi Kasus: Pantai Mangarabombang-Galesong Selatan, Kabupaten Takalar), in Seminar Nasional Fisika Makassar, pp. 117-123.

Nurjaya, I.W. \& Atmadipoera, A.S. 2020. Analisis Perubahan Garis Pantai di Wilayah Pantai Barat Kabupaten Tanah Laut Kalimantan Selatan. Jurnal IImu dan teknologi Kelautan Tropis. 12(1):211-222.

Pendleton, E.A., Thieler, E. R. \& Williams, S.J. 2005. Coastal Vulnerability Assessment of War in The Pacific National Historical Park (WAPA) to Sea-Level Rise'. US Geological Survey. Virginia. USA. 25 hal.

Purba, M. \& Jaya, I. 2004. Analisis Perubahan Garis Pantai dan Penutupan Lahan antara Way Penet dan Way Sekampung, Kabupaten Lampung Timur. Jurnal IImuIImu Perairan dan Perikanan Indonesia. 11 (2):109-121.

Purba, M., Nurjaya, I.W., Pawitan, H. \& Siregar, V.P., 2011 . Studi perubahan garis pantai di delta sungai Jeneberang, Makassar. IImu dan Teknologi Kelautan Tropis, 3(2):112126.

Ruiz, L.A., Pardo, J.E., Almonacid, J. \& Rodriguez, B. 2007. Coastline Automated Detection and Multi-resolution Evaluation using Satellite Images. Proceedings of Coastal Zone 07 Portland, Oregon, July 22-26.

Thieler, E.R., Himmelstoss, E.A., Zichichi, J.L. \& Ergul, A. 2009. The Digital Shoreline Analysis System (DSAS) version 4.0-an ArcGIS Extension for Calculating Shoreline Change. US Geological Survey Open-File Report 2008-1278, ver. 4.2. 81 p. 